
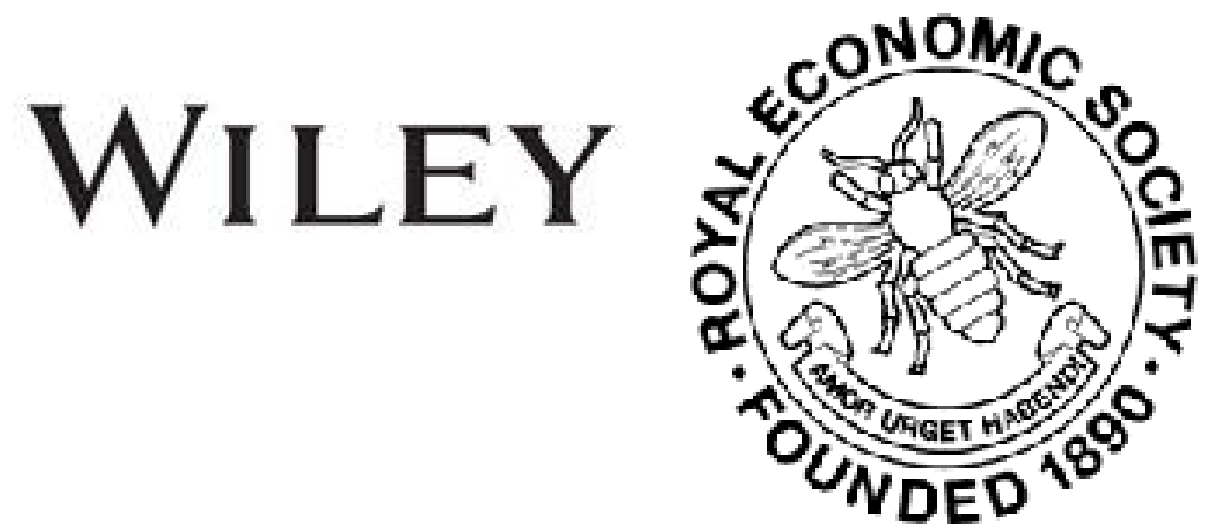

Review

Authors(s): J. C. Stamp

Review by: J. C. Stamp

Source: The Economic Journal, Vol. 31, No. 124 (Dec., 1921), pp. 512-516

Published by: Wiley on behalf of the Royal Economic Society

Stable URL: http://www.jstor.org/stable/2223084

Accessed: 30-03-2016 01:53 UTC

Your use of the JSTOR archive indicates your acceptance of the Terms \& Conditions of Use, available at

http://about.jstor.org/terms

JSTOR is a not-for-profit service that helps scholars, researchers, and students discover, use, and build upon a wide range of content in a trusted digital archive. We use information technology and tools to increase productivity and facilitate new forms of scholarship. For more information about JSTOR, please contact support@jstor.org.

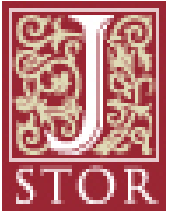

Wiley, Royal Economic Society are collaborating with JSTOR to digitize, preserve and extend access to The Economic Journal

http://www.jstor.org 
as difficult, as though the inductive hypothesis were either of these, to remove from the organon of thought the inductive method, which can only be based on it or on something like it" (p. 364).

These ultimate speculations, going, as they do, to the root of the theory of knowledge, are not suitable for discussion in the pages of this Journal. It is not, however, merely the fact that Mr. Keynes is a distinguished economist that warrants a review of his work here. For, though the philosophy of probability lies outside their field, students of economics have, perforce, to make frequent use of probable inference. This is so even in pure theory, when we lay it down, for example, that curves of demand and supply are likely to be continuous; when we assume, as we must do in certain problems of taxation, some definite relation between the elasticity of demand at a point, taken as known, and the elasticity at neighbouring points; or when we recognise, with Professor Edgworth, that certain problems of monopoly have a less secure solution than others, because, to treat them successfully, it is necessary to know the sign, not merely of the first, but also of the second, differential of the price-quantity function. In practical work, when we are endeavouring to disentangle causes and to foresee effects, particularly if statistical correlations form a part of our material, we are grappling even more directly with particular instances of the class of problems of which Mr. Keynes is seeking a general view. A study of that general view may be of high value in our narrower researches. For the problems which Mr. Keynes has touched he has not only illuminated with a marvellous lucidity of style, but has also substantially advanced. Economists will recognise with pride what one of their number has accomplished in another field, and will look forward with added zest to his next essay in their own.

\section{A. C. Pigou}

The Taxation of Excess Profits in Great Britain; A study of the British Excess Profits Duty in relation to the problem of Excess Profits Taxation in the United States. A Report prepared for the Committee on War Finance of the American Economic Association by Robert Murray HaIa, Ph.D., assisted by GEORGE E. Holmes of the New York Bar.

IN the spring of 1919 Dr. Haig was delegated by the War Finance Committee of the American Economic Association to 
conduct an investigation into the Excess Profits Duty in this country, and to inquire particularly, first, into the way in which certain problems which had caused difficulty and dissatisfaction in America had been dealt with in British law and practice; secondly, into any points in which our administrative schemes might suggest improvements in their own; and thirdly, into the views of economists, officials and business men upon the economic effects of the special profits tax and its suitability for a permanent place in the revenue scheme. In the report which resulted from this investigation we have mainly an account of those aspects of our system which were likely to be of value to American students and financiers; but, at the same time, Dr. Haig has dealt with many matters of permanent and general interest. $\mathrm{He}$ had unrivalled opportunities for obtaining first-hand information, and the list of people with whom he came into contact is an imposing one. It is not surprising that a number of points are touched upon in his work, particularly in regard to inner political or historical facts, which cannot be found elsewhere. Upon the technical parallel drawn between the two systems it will suffice to say here that the work is exceedingly well done, the most difficult problems being handled with proportion and accuracy. Upon the second matter, relating to administrative efficiency, he has virtually nothing but the highest praise for us. $\mathrm{He}$ is impressed by the high degree of authority and responsibility given to our local officers, and the measure of trust that exists between them and the public. There could scarcely be a greater contrast than that afforded by the attitude of the British administration and that of the ordinary local Collector of Internal Revenue in the United States, and much of the dissatisfaction with direct taxation, which unquestionably exists in America, is traceable to strict, petty stickling over minor inconsequential details. Dr. Haig realises that such wide decentralisation of delicate and involved duties was only made possible by a long-established and highly developed Civil Service, and that therefore the United States has no prospect of immediately following suit.

For readers of this JouRNaL the section dealing with fiscal and economic consequences will probably be the most interesting. Dr. Haig spared no pains to compare the actual impressions of officials and business men with the results of general abstract reasoning. It is agreed that in some instances the liability to duty was taken into account when arriving at prices under Government contracts, so that the Government had to pay more for its supplies than it would have done if there had been no 
duty, but after 1917 a closer control of conditions reduced this element to unimportance. The extent to which the Government were made "to pay their own taxes" cannot be even approximately estimated, but with such urgent demand, with an unlimited vote of credit, and with all suppliers engaged in full production, it must have been appreciable. As might be expected, the most diverse views were expressed as to the effect of the duty upon general prices; some merchants thought it had no effect in raising them, while others thought it all-important. The economist's view that such a tax could not operate to increase competitive prices, and must also come out of all monopoly profits, found little support in the daily press, which blamed the duty very largely for prevailing high prices. Dr. Haig is probably near the truth when he surmises that the existence of the duty led to a speedier approach to a potentially higher price-" one suspects the tax has been seized upon as an excuse for monopoly prices which would be just as high in the absence of the duty."

Dr. Haig refers to one manufacturer who told him that when his concern found itself, after a number of lean years, in possession of a large stock, and confronted by a demand so immense that it was in a position to ask almost any price, the fact that the duty had to be paid influenced the directors to charge a higher price than they otherwise would have asked, and he comments: "such tender-hearted tyros at profiteering, who depend- on the tax to give them moral courage to charge what they can get for their goods in the market, are probably rare economic phenomena and, moreover, unless they happen to be selling directly to the consumer, anything they refrain from adding to their price is probably added to it by the next man in the marketing chain, so that the ultimate retail price is no lower."

Although agreeing with accepted views as to the incidence of a tax on a margin, Dr. Haig thinks that there may be long-period indirect effects in the direction of increased prices from a business tax of this kind. Such effects would arise from " laxity in management and extravagance." He might, with advantage, have been more expansive on the connection or distinction between what may be called the static incidence of the tax with a given flow of commodities and given state of production, and the ultimate effects set up by reactions through the interior mechanism of the tax. In substance, it amounted to a partnership between the Government and the taxpayer for a limited period, where the taxpayer, at small expense to himself, could call the tune with regard to expenditure of two kinds. First we have that expendi- 
ture which would react on the business in future years, and give the taxpayer the undiminished benefit later on, such as large outlay on advertising and thorough overhauling of buildings with renewals and repairs. It is true there were physical limitations here, but it was worth the taxpayer's while to get the work done even at a much higher price, since only some 20 per cent. of it fell upon himself. If it had all fallen to be borne by himself it might have been postponed indefinitely, and therefore, to some extent, the duty forced production into channels that might suitably have been delayed till after the war, and in pro tanto starving the supply of essential objects, increased their price. Excessive expenditure upon advertising, though building up a future goodwill for the particular business, may not have had any beneficial effects on industry as a whole, either then or now, except so far as such advertising was strictly truthful, and brought to the front the goods most worthy of recognition by the public. To some extent it forced production into least advantageous channels at critical times, but it may have enabled essential news services to continue which would otherwise have gone under, so that it possibly indirectly cheapened other products. The second class of expenditure includes extravagance or persistence in wasteful and careless methods : unless, however, these methods also obtained amongst " non-E.P.D." payers producing " at the margin," they would not appear to have influenced price, but only to have depleted a certain range of individual profits. In so far as the more prosperous concerns are pioneers in improvements which get generally adopted, and in so far as they " set the pace," the negative action of E.P.D. in discouraging such concerns from seeking the best methods would also have retarded the general lowering of costs, including those of the marginal concerns, and so have maintained prices unnecessarily. The deflection of a part of economic profit away from the profit-maker and the Government to the wage-earners of a particular business, doubtless also has set a pace for that industry as a whole, and therefore, for all industries indirectly, and increased costs at the margin to some extent. The purchasing power of the Government and the profit-maker was reduced, and that of the wage-earner increased by a like sum, but as the Government had to secure the goods, anything it failed to get by taxation and direct loans had to be obtained by inflation, which therefore raised prices, except to the extent that the wage-earner put the extra receipts in question into War Loan, and refrained from spending them.

It must be remembered that the economic importance of 
" non-E.P.D." concerns in their effect upon the incidence of the tax, gradually got less as general inflation brought more and more of them-even with restricted trade-above their fixed pre-war standards of profit. There is doubtless much truth in Dr. Haig's summary of the effects of "discouragement": "The British business men allege that their duty tends to sanctify the traditional profits of well-established concerns, rendering them immune from competition, and that it tends to discriminate against young and growing businesses. They claim that it places a penalty on aggressiveness and ability and a bounty on conservatism." But, as he rightly points out, it does not lie with those who must use the "repression" argument to urge so vehemently that any tax that is paid is passed on to the consumer in higher prices than would otherwise have existed.

The economic effects on prices in the long run, of such interference with the normal course as the conserving of wasting assets, such as minerals, or the postponement of rubber tapping until the E.P.D. should have passed away, and the results of depleting funds that would have been available for expansion and development, it is too early even yet to appraise ; and therefore Dr. Haig's reasoned opinions of 1920 may have to be materially supplemented before a complete picture can be drawn. Meanwhile, the extension of the duty virtually to August 1921, with the great liabilities it is throwing upon the Exchequer, seems likely to turn this scheme of taxation in many instances into the most complicated arrangement ever devised for borrowing money for five years without paying interest on it.

J. C. StAMP

The English Capital Market. By F. Lavington. (London: Methuen \& Co. 1921. Pp. 297. Price 18s.)

THIs careful exposition of the relation of the Money Market to the industrial system will undoubtedly appeal to students of economic theory. The writer has been well disciplined in a rigorous school of analytic subtlety. But to the average City man, a book on the "English Capital Market," which barely recognises the changes of the past six years, but deals with the Quantity Theory (developing Dr. Marshall's evidence before the Royal Commission of 1888); which pays hardly any attention to the position of London as a centre of international finance, but discusses Uncertainty Bearing and Insecurity in the style of Professor Pigou-such a book cannot fail to seem rather 